\title{
時間の経過とともに観測值のいくつかが母集団を 移動する場合の判別分析について
}

\author{
中 西寛 子* \\ DISCRIMINANT ANALYSIS WHEN SOME DATA MOVE FROM ONE \\ POPULATION TO ANOTHER IN THE PROCESS OF TIME
}

Hiroko NAKANISHI

\begin{abstract}
In this paper Fisher's linear discriminant function is investigated in which some data move from one to the other of two populations in the process of time. Utilizing the model for such kind of data, the mean vectors, common covariance matrix, discriminant coefficient vector, and cutting point are derived for each time. Two theorems for the coefficient vector and cutting point are obtained and certain numerical results for them are presented.

From these theorems and numerical results, it is shown that if the data which change populations are close to the boundary of the end population, they do not greatly affect the coefficient vector and cutting point.

Lastly, we show the example of prevention of geriatric diseases and discuss the coefficient vector and cutting point.
\end{abstract}

\section{1. 研究の動機}

判別分析では各母集団より得られた観測値を用いて 判別関数を決定し分析するが，観測值のうちのいくつ かが時間の経過とともに属している母集団を移動する ため, 各変量に対する判別係数や判別点が分析時に依 存することがある。医学の分野では老人病(心筋梗塞, 脳卒中など)の追跡調查の研究にこの例がみられる.具 体的淠説明すと, 健康者 $n$ 名の集団検診後 $x$ 年経過 したとさの調査において $n_{1}$ 名が発症, ついで $y(y=x$ $+z, 0<z)$ 年後の調査に招いてはさらに $n_{2}$ 名が発症 した場合， $n_{2}$ 名が非発症群から発症群へ $z$ 年間に移 動したことになる。初めの集団検診で得られた値のみ を用いるので, 判別係数べクトルや判別点は, $x$ 年後に おける分析と $y$ 年後にお法る分析とでは移動した $n_{2}$ 名の観測值のため異なる。たとえば，脳血管障害の発 症について廣田安夫（1978）が研究を行っている。彼 は, 集団検診後 5 年半後に発症した者 70 名と非発症者

* 北海道大学工学部情報工学 (Division of Information Engineering, Graduate School of Engineering, Hokkaido University)
1,405名（対照群として 70 名を選ぶ）をもとに判別分 析を行っている。この分析時点を 5 年半から 3 年（文 たは 8 年) に変光た場合, 発症者数が減り（または増 し), 得られる解は変化すると考学られる。をこで,「検 診後, 何年以内に発症しだものを発症群としてとらえ れば良いか」という問題が生じる.

本研究の目的は時間の経過によって母集団を変える 観測値が判別係数ベクトルや判別点にどの様な影響を もたらすかをモデルをたてて数值的に検証し，実例を 示すことによって上記のよらな問題を考察することで ある。ここで用いる判別関数は Fisher の線形判別関数 (Fisher (1936)) である.

\section{Fisher の線形判別関数}

母集団 $\Pi_{i}^{*}$ から得られた $n_{i}^{*}$ 個の 観測值 $\boldsymbol{x}_{i j}\left(i=1,2, j=1, \cdots, n_{i}^{*}\right)$ に対する Fisher の線 形判別関数について説明する。 $p$ 変量ベクトル $\boldsymbol{x}^{\prime}=$ $\left(x_{1}, \cdots, x_{p}\right)$ に関する線形モデル $f(\boldsymbol{x})=a_{1} x_{1}+\cdots$ $+a_{p} x_{p}$ の5ち両母集団の差を最も明確に説明する判 別係数ベクトル $\boldsymbol{a}^{\prime}=\left(a_{1}, \cdots, a_{p}\right)$ は, 両母集団に対する 標本平均ベクトル $\overline{\boldsymbol{x}}_{i}^{*}$, 標本共分散行列 $S_{i}^{*}(i=1,2)$ と 
それから得られる標本群内共分散行列 $S_{w}^{*}$ 用いて,

$$
\boldsymbol{a}^{\prime}=\left(\overline{\boldsymbol{x}}_{1}^{*}-\overline{\boldsymbol{x}}_{2}^{*}\right)^{\prime} S_{w}^{*-1}
$$

と表される。ここで，

$$
\begin{aligned}
& \overline{\boldsymbol{x}}_{i}^{*}=\frac{\sum_{j=1}^{n_{i}^{*}} \boldsymbol{x}_{i j}}{n_{i}^{*}}, \\
& S_{i}^{*}=\frac{\sum_{j=1}^{n_{*}^{*}}\left(\boldsymbol{x}_{i j}-\overline{\boldsymbol{x}}_{i}^{*}\right)\left(\boldsymbol{x}_{i j}-\overline{\boldsymbol{x}}_{i}^{*}\right)^{\prime}}{n_{i}^{*}}, \\
& S_{w}^{*}=\frac{n_{1}^{*} S_{1}^{*}+n_{2}^{*} S_{2}^{*}}{n_{1}^{*}+n_{2}^{*}}
\end{aligned}
$$

である ${ }^{1)}$. Fisherの線形判別関数 $f(\boldsymbol{x})$ は求められた判 別係数べクトル $\boldsymbol{a}$ によってつぎのように作られる.

$$
f(\boldsymbol{x})=\boldsymbol{a}^{\prime} \boldsymbol{x} .
$$

新しく得られた観測值 $\boldsymbol{x}$ に対して $f(\boldsymbol{x})$ がある定数 $h$ (これを判別点と呼ぶ)より大さいときとの観測值 $\boldsymbol{x}$ を母集団 $\Pi_{1}^{*}$ に割り当て，そらでないときには母集団 $\Pi_{2}^{*}$ に割り当てる. ここでは, 判別点 $h=\frac{\boldsymbol{a}^{\prime}\left(\overline{\boldsymbol{x}}_{1}^{*}+\overline{\boldsymbol{x}}_{2}^{*}\right)}{2}$ を用いる.この判別点の極限は二つの母集団の事前確 率と誤判別に対する損失が等しく，さらに，同一の共 分散行列を持つ正規分布に従うとき, 両母集団の誤判 別に沶ける損失を等しくかつ最小にする (Anderson (1984))。 。た，母集団の離れ具合いを示す尺度として $\lambda=\frac{n_{1}^{*} n_{2}^{*} \boldsymbol{a}^{\prime}\left(\overline{\boldsymbol{x}}_{1}^{*}-\overline{\boldsymbol{x}}_{2}^{*}\right)}{\left(n_{1}^{*}+n_{2}^{*}\right)^{2}}$ を用いる。これは, $\frac{\boldsymbol{a}^{\prime} S_{B}^{*} \boldsymbol{a}}{\boldsymbol{a}^{\prime} S_{W}^{*} \boldsymbol{a}} て ゙$ あり，值が大きい痤ど両母集団が離れていることを示 す.ただし， $S_{B}^{*}$ は標本群間共分散行列である。最後に, 上で示した判別点 $h$ を用いた Fisher の線形判別法は データの平行移動, 回転, スケールの拡大縮小に対し て不変であることを注意しておく。

\section{3. モ デル}

時間が経つにつれ母集を変える観測值のモデルを考 えるにあたり Lachenbruch $(1966,1974,1979)$ の初期 誤分類に対する研究に用いられたモデルを応用する. 彼は，母集団 $\Pi_{1}^{*}$ から得られたとされている観測值の らち $\alpha_{1}$ の割合のものが実際は母集団 $\Pi_{2}^{*}$ から得られ て抢り, また, 母集団 $\Pi_{2}^{*}$ から得られたとされている観

1）一般に標本共分散行列には不偏推定量を用いるが ここでは後の計算を容易にするため上記のように 置いた。なお, 本研究に拈ける結果は不偏推定量を 用いても大きく異ならない。
測値のうち $\alpha_{2}$ の割合のものが実際は母集団 $\Pi_{1}^{*}$ から 得られている場合についての誤判別率を初期類分類の ない場合と比較している、本研究は, 観測值のらち $\alpha$ の割合のものが母集団 $\Pi_{1}^{*}$ から母集団 $\Pi_{2}^{*}$ に移動した と考光, 移動前と移動後を比較することが目的である ので彼の研究に用いたモデルを書さ直すことによって 次のようなモデルが得られる.

三つの群 $\Pi_{1}, \Pi_{2}, \Pi_{3}$ よりそれぞれ標本平均ベクト ル $\overline{\boldsymbol{x}}_{j}$ と標本共分散行列 $S_{j}(j=1,2,3)$ が得られたと する. ある時点 $t_{1}$ では群 $\Pi_{1}$ と群 $\Pi_{2}$ が母集団 $\Pi_{1}^{*}$ を なし, 群 $\Pi_{3}$ が母集団 $\Pi_{2}^{*}$ をなす。 また, ある時点 $t_{2}\left(t_{1}\right.$ $\left.<t_{2}\right)$ では群 $\Pi_{1}$ が母集団 $\Pi_{1}^{*}$ を, 群 $\Pi_{2}$ と群 $\Pi_{3}$ が母 集団 $\Pi_{2}^{*}$ を作る。つまり, 二番目の群 $\Pi_{2}$ が母集団 $\Pi_{1}^{*}$ から母集団 $\Pi_{2}^{*}$ へ移動したことになる。 また，各群 $\Pi_{j}$ の標本数を $n_{j}\left(j=1,2,3, n_{1}+n_{2}+n_{3}=n\right)$ とする.

時点 $t_{k}(k=1,2)$ における母集団 $\Pi_{i}^{*}$ の標本平均べ クトル $\overline{\boldsymbol{x}}_{i}^{*(k)}$ と標本共分散行列 $S_{i}^{*(k)}(i=1,2)$ は次の ようになる。

$$
\begin{aligned}
\overline{\boldsymbol{x}}_{1}^{*(1)}= & \frac{n_{1}}{n_{1}+n_{2}} \overline{\boldsymbol{x}}_{1}+\frac{n_{2}}{\left(n_{1}+n_{2}\right)} \overline{\boldsymbol{x}}_{2}, \overline{\boldsymbol{x}}_{2}^{*(1)}=\overline{\boldsymbol{x}}^{3}, \\
S_{1}^{*(1)}= & \frac{n_{1}}{n_{1}+n_{2}} S_{1}+\frac{n_{2}}{n_{1}+n_{2}} S_{2} \\
& +\frac{n_{1} n_{2}}{\left(n_{1}+n_{2}\right)^{2}}\left(\overline{\boldsymbol{x}}_{1}-\overline{\boldsymbol{x}}_{2}\right)\left(\overline{\boldsymbol{x}}_{1}-\overline{\boldsymbol{x}}_{2}\right)^{\prime}, \\
S_{2}^{*(1)}= & S_{3}, \\
\overline{\boldsymbol{x}}_{1}^{*(2)}= & \overline{\boldsymbol{x}}_{1}, \\
\overline{\boldsymbol{x}}_{2}^{*(2)}= & \frac{n_{2}}{n_{2}+n_{3}} \overline{\boldsymbol{x}}_{2}+\frac{n_{3}}{n_{2}+n_{3}} \overline{\boldsymbol{x}}_{3}, \\
S_{1}^{*(2)}= & S_{1}, \\
S_{2}^{*(2)}= & \frac{n_{2}}{n_{2}+n_{3}} S_{2}+\frac{n_{3}}{n_{2}+n_{3}} S_{3} \\
& +\frac{n_{2} n_{3}}{\left(n_{2}+n_{3}\right)^{2}}\left(\overline{\boldsymbol{x}}_{2}-\overline{\boldsymbol{x}}_{3}\right)\left(\overline{\boldsymbol{x}}_{2}-\overline{\boldsymbol{x}}_{3}\right)^{\prime} .
\end{aligned}
$$

従って, 時点 $t_{k}(k=1,2)$ に打ける標本群内共分散行列 は次の様に求められる。

$$
\begin{aligned}
& S_{w}^{*(1)}=S+\frac{n_{1} n_{2}}{n\left(n_{1}+n_{2}\right)}\left(\overline{\boldsymbol{x}}_{1}-\overline{\boldsymbol{x}}_{2}\right)\left(\overline{\boldsymbol{x}}_{1}-\overline{\boldsymbol{x}}_{2}\right)^{\prime}, \\
& S_{W}^{*(2)}=S+\frac{n_{2} n_{3}}{n\left(n_{2}+n_{3}\right)}\left(\overline{\boldsymbol{x}}_{2}-\overline{\boldsymbol{x}}_{3}\right)\left(\overline{\boldsymbol{x}}_{2}-\overline{\boldsymbol{x}}_{3}\right)^{\prime},
\end{aligned}
$$

ここで

$$
S=\frac{n_{1} S_{1}+n_{2} S_{2}+n_{3} S_{3}}{n} .
$$

また，判別係数ベクトルおよび判別点の式が次の様に 求められる. 


$$
\begin{aligned}
\boldsymbol{a}^{(k)^{\prime}}=\left(\overline{\boldsymbol{x}}_{1}^{*(k)}-\overline{\boldsymbol{x}}_{2}^{*(k)}\right)^{\prime} S_{W}^{*(k)^{-1}} & (k=1,2), \\
h^{(k)}=\frac{\boldsymbol{a}^{(k) \prime}\left(\overline{\boldsymbol{x}}_{1}^{*(k)}+\overline{\boldsymbol{x}}_{2}^{*(k)}\right)}{2} & (k=1,2) .
\end{aligned}
$$

\section{4. 判別係数ベクトルと判別点への影響}

本章では，母集団を変える観測值が判別係数ベクト ルと判別点へ执よぼす影響を定理と数值例によって考 察する. Fisherの線形判別法がデータの平行移動, 回 転, スケールの拡大縮小に対して不変であることより， 一般性を失うことなく次の仮定を置くことがでさる.

$$
\begin{aligned}
& \overline{\boldsymbol{x}}_{1}{ }^{\prime}=\mathbf{0}^{\prime}, \\
& \overline{\boldsymbol{x}}_{2}{ }^{\prime}=\left(x_{21}, x_{22}, 0, \cdots, 0\right), \\
& \overline{\boldsymbol{x}}_{3}{ }^{\prime}=\left(x_{3}, 0, \cdots, 0\right), \\
& 0<x_{3} .
\end{aligned}
$$

また，次の条件を加える。

$$
0 \leqq x_{21} \leqq x_{3} .
$$

これは変化する群 $\Pi_{2}$ が群 $\Pi_{1}$ と群 $\Pi_{3}$ の間にあると いう条件である。ここでの考察に拈いて二つの状況を 考党る、 $x_{22}=0$ の場合とそらでない場合である， $x_{22}=$ 0 の場合とは群 $\Pi_{2}$ の標本平均ベクトル $\overline{\boldsymbol{x}}_{2}$ が群 $\Pi_{1}$ の 標本平均ベクトル $\overline{\boldsymbol{x}}_{1}$ と群 $\Pi_{3}$ の標本平均ベクトル $\overline{\boldsymbol{x}}_{3}$ の線分上にあるということである。

\section{$4.1 x_{22}=0$ の場合}

$x_{22}=0$ の場合は $\frac{\boldsymbol{a}^{(1)}}{\left\|\boldsymbol{a}^{(1)}\right\|}=\frac{\boldsymbol{a}^{(2)}}{\left\|\boldsymbol{a}^{(2)}\right\|}$ が成り立つので判 別係数ベクトルの方向が二つの時点に括いて同じであ ることがわかる。しかしながら，この判別係数べクト ルが不変である状況に沶いても判別点の不変性は得ら れないことが次の定理によって示される.

定理 1. $x_{22}=0$ の条件のもとで， $n_{2}=0$ ならば $\frac{h^{(1)}}{\left\|\boldsymbol{a}^{(1)}\right\|}=\frac{h^{(2)}}{\left\|\boldsymbol{a}^{(2)}\right\|}$ となる。 またそのときに限る(この証 明は付録 1 に示す).

\begin{tabular}{|c|c|c|c|c|c|}
\hline$x_{21}$ & $p_{1}$ & $p_{2}$ & $p_{3}$ & $h^{(1)}$ & $\Delta h$ \\
\hline \multirow[t]{6}{*}{0.00} & \multirow[t]{2}{*}{0.3} & 0.2 & 0.5 & -1.000 & 0.286 \\
\hline & & 0.1 & 0.6 & -1.000 & 0.143 \\
\hline & \multirow[t]{2}{*}{0.5} & 0.2 & 0.3 & -1.000 & 0.400 \\
\hline & & 0.1 & 0.4 & -1.000 & 0.200 \\
\hline & \multirow[t]{2}{*}{0.7} & 0.2 & 0.1 & -1.000 & 0.667 \\
\hline & & 0.1 & 0.2 & -1.000 & 0.333 \\
\hline \multirow[t]{6}{*}{0.25} & \multirow[t]{2}{*}{0.3} & 0.2 & 0.5 & -1.100 & 0.314 \\
\hline & & 0.1 & 0.6 & -1.062 & 0.170 \\
\hline & \multirow[t]{2}{*}{0.5} & 0.2 & 0.3 & -1.071 & 0.371 \\
\hline & & 0.1 & 0.4 & -1.042 & 0.192 \\
\hline & \multirow[t]{2}{*}{0.7} & 0.2 & 0.1 & -1.056 & 0.556 \\
\hline & & 0.1 & 0.2 & -1.031 & 0.281 \\
\hline \multirow[t]{6}{*}{0.50} & \multirow[t]{2}{*}{0.3} & 0.2 & 0.5 & -1.200 & 0.343 \\
\hline & & 0.1 & 0.6 & -1.125 & 0.196 \\
\hline & \multirow[t]{2}{*}{0.5} & 0.2 & 0.3 & -1.143 & 0.343 \\
\hline & & 0.1 & 0.4 & -1.083 & 0.183 \\
\hline & \multirow[t]{2}{*}{0.7} & 0.2 & 0.1 & -1.111 & 0.444 \\
\hline & & 0.1 & 0.2 & -1.063 & 0.229 \\
\hline \multirow[t]{6}{*}{0.75} & \multirow[t]{2}{*}{0.3} & 0.2 & 0.5 & -1.300 & 0.371 \\
\hline & & 0.1 & 0.6 & -1.187 & 0.223 \\
\hline & \multirow[t]{2}{*}{0.5} & 0.2 & 0.3 & -1.214 & 0.314 \\
\hline & & 0.1 & 0.4 & -1.125 & 0.175 \\
\hline & \multirow[t]{2}{*}{0.7} & 0.2 & 0.1 & -1.167 & 0.333 \\
\hline & & 0.1 & 0.2 & -1.094 & 0.177 \\
\hline \multirow[t]{6}{*}{1.00} & \multirow[t]{2}{*}{0.3} & 0.2 & 0.5 & -1.400 & 0.400 \\
\hline & & 0.1 & 0.6 & -1.250 & 0.250 \\
\hline & \multirow[t]{2}{*}{0.5} & 0.2 & 0.3 & -1.286 & 0.286 \\
\hline & & 0.1 & 0.4 & -1.167 & 0.167 \\
\hline & \multirow[t]{2}{*}{0.7} & 0.2 & 0.1 & -1.222 & 0.222 \\
\hline & & 0.1 & 0.2 & -1.125 & 0.125 \\
\hline
\end{tabular}

$x_{22}=0$ の場合でも判別点が影響を受けることがわ かったのでその影響の程度を $p_{1}=\frac{n_{1}}{n}, p_{2}=\frac{n_{2}}{n}, p_{3}=$ $\frac{n_{3}}{n}$ と $x_{21}$ にいくつかの值を与えることによって調べ る.ただし $, x_{3}=1, \frac{\sigma^{11}}{2 \sqrt{\sum_{j=1}^{p}\left(\sigma^{i 1}\right)^{2}}}=1\left(S^{-1}=\left(\sigma^{i j}\right)\right)$ とす る. 変化量を次のように置く.
表 1 変化量 $\Delta h$ の値

$$
\begin{aligned}
\Delta h & =\left|\frac{h^{(2)}}{\left\|\boldsymbol{a}^{(2)}\right\|}-\frac{h^{(1)}}{\left\|\boldsymbol{a}^{(1)}\right\|}\right| \\
& =\left|\frac{p_{2} x_{21}+p_{3}}{p_{2}+p_{3}}-\frac{p_{2} x_{21}+p_{1}+p_{2}}{p_{1}+p_{2}}\right|
\end{aligned}
$$

変化量 $\Delta h$ が 0 のを二つの時点での分析は同じであ り，その值が大きいとき判別点が大きく異なる.表 1 で 示された結果から次のようなことが言える。

i) $p_{2}=0.2$ のをの㴗らが $p_{2}=0.1$ のときよりも 両変化量の值は大さく, 約 2 倍である.

ii）群 $\Pi_{1}$ の標本数が他の群に比べて大きく群 $\Pi_{2}$ が群 $\Pi_{3}$ に近いと変化量 $\Delta h$ は小さい.

\section{$4.2 x_{22} \neq 0$ の場合}

(4.1) の仮定と（4.2）の条件のもとで $x_{22} \neq 0$ 場合を 


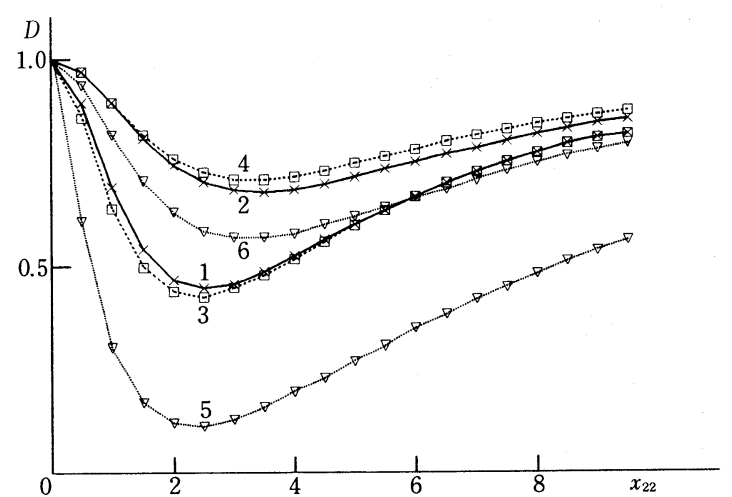

図1(a) $x_{21}=0.0$

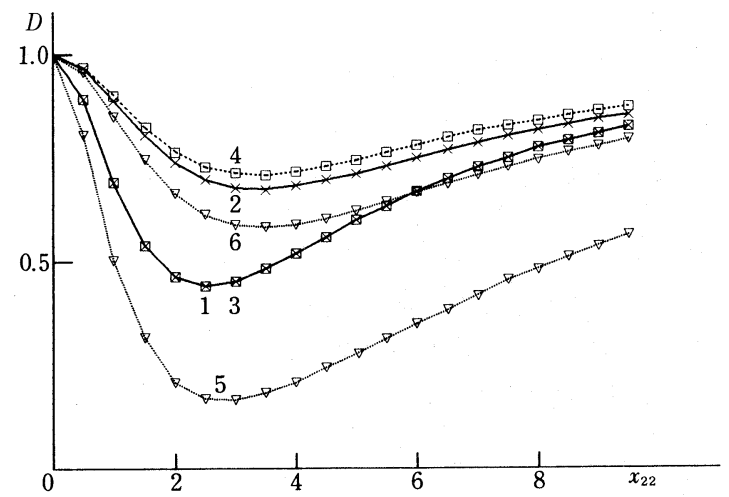

図1(b) $x_{21}=0.5$

1. $p_{1}=0.3, p_{2}=0.2, \mathrm{p}_{3}=0.5$

2. $p_{1}=0.3, p_{2}=0.1, p_{3}=0.6$

3. $p_{1}=0.5, p_{2}=0.2, p_{3}=0.3$

4. $p_{1}=0.5, p_{2}=0.1, p_{3}=0.4$

5. $p_{1}=0.7, p_{2}=0.2, p_{3}=0.1$

6. $p_{1}=0.7, p_{2}=0.1, p_{3}=0.2$

図 $1 x_{22}$ に対する値 $D$ の変化

考える. $x_{22} \neq 0$ ならば $\frac{\boldsymbol{a}^{(1)}}{\left\|\boldsymbol{a}^{(1)}\right\|} \neq \frac{\boldsymbol{a}^{(2)}}{\left\|\boldsymbol{a}^{(2)}\right\|}$ と思われる. 特 に, $S$ が単位行列 $I$ のをきついてこのことを示す.

定理 2. $S=I$ で $x_{22}>(<) 0$ のとき, $a_{1}^{(1)} a_{2}^{(1)}<$ $(>) 0, a_{1}^{(2)} a_{2}^{(2)}>(<) 0, a_{3}^{(k)}=\cdots=a_{p}^{(k)}=0$, ここで, $\boldsymbol{a}^{(k)^{\prime}}$ $=\left(a_{1}^{(k)}, a_{2}^{(k)}, \cdots, a_{p}^{(k)}\right)(k=1,2)$ (この証明は付録 2 に 示す).

このように $x_{22} \neq 0$ のとき母集団を変える観測值が 判別係数べクトルに影響を掞よぼすことがわかったの で, 值 $D$ を次の様に与光 $x_{22}$ に対する判別係数べクト
ルのベクトルの方向としての変化を調ベる.

$$
D=\cos \theta=\frac{\left(\boldsymbol{a}^{(1)}, \boldsymbol{a}^{(2)}\right)}{\left\|\boldsymbol{a}^{(1)}\right\|\left\|\boldsymbol{a}^{(2)}\right\|}
$$

值 $D$ が 1 のときは判別係数ベクトルが変化しなかっ たことを示し，值が小さくなるほど変化が大さいこと を示す。

図 1 は $p_{1}, p_{2}, p_{3}$ と $x_{21}$ にいくつかの值を与光 $x_{22}$ を動かしたものである。ただし， $x_{3}=1, S=I$ とする。 図 1 から見られるいくつかの結果を以下に示す.

iii） $x_{22}$ の值が大きくかつ 3 よりも小さいとき值 $D$ も小さい.ただし， $x_{22} \rightarrow \infty$ のを $D \rightarrow 1$ (付録 3 の (1)，(2)，（3)，（4）式を（4.3）式に代入すると 得られる).

iv） $p_{2}=0.2$ のときのと比べると $p_{2}=0.1$ のときの 方が值 $D$ は 1 に近い.

v）群 $\Pi_{3}$ の標本数が他の群に比べて小さいとさ值 $D$ は小さい.

以上に述べた数值例による結果のらちi)とiv)はごく 自然であるが, 残りの三つは興味深い結果である. 結 果の ii) と iii) は定理 1 とともに考光合わせると「群 $\Pi_{1}$ の標本数が他の群に比べて大きな場合, 群 $\Pi_{3}$ の近 傍にあり群 $\Pi_{1}$ の方向にある観測値が群 $\Pi_{1}$ より群 $\Pi_{3}$ に移動しても判別係数ベクトルや判別点に（定数倍を 除いて）影響を与えない」といら結論が導かれる。

\section{5. 具体例と考察}

老人病の研究では，ある年に多くの健康者に集団検 診を実施し, 後の追跡調査に打いて発症者のデータか ら疾病の要因を調べることがよく行われる。十分な発 症群を得るためには長い年月が必要となるが,一方, 初 めの検診で得られたデータの効力は年月とともに減少 する。この様な問題を一挙に解決することは容易では ないが，第 4 章で考察したことから判別係数べクトル の動きを調べることによって糸口を見いだしたい。

脳卒中の例を取り上げる，ただし，説明を容易にす るため変量や標本数を少なくしている, ある年, 四項 目: 肥满度, 収縮期血圧, 抎張期血圧, 血清総コレス テロールの検査が 48 名の健康者に実施され次の年に 4 名が発症, また次の年に 4 名が発症…した(表 2). 各 変量を全体の標本平均之標本分散で標準化し, 判別係 数ベクトルと判別点を求め, 判別係数ベクトルのノル ムで割ることによって正規化したものを表 3 に示し た.さらに，各調査年に対して母集団の離れ具合いを 
表 2 脳卒中のデータ

\begin{tabular}{|c|c|c|c|c|c|}
\hline \multirow{2}{*}{ 発 症 年 } & \multirow{2}{*}{ 番号 } & \multicolumn{4}{|c|}{ 項目 } \\
\hline & & 1 & 2 & 3 & 4 \\
\hline \multirow{4}{*}{$\begin{array}{l}\text { 検敦日 } \\
\sim 1 \text { 年後 }\end{array}$} & 1 & 71 & 126 & 90 & 241 \\
\hline & 2 & 245 & 172 & 112 & 211 \\
\hline & 3 & 16 & 136 & 94 & 184 \\
\hline & 4 & -117 & 136 & 88 & 251 \\
\hline \multirow{4}{*}{$\begin{array}{l}1 \text { 年後 } \\
\sim 2 \text { 年後 }\end{array}$} & 5 & -64 & 140 & 90 & 138 \\
\hline & 6 & 96 & 104 & 66 & 141 \\
\hline & 7 & 108 & 132 & 88 & 248 \\
\hline & 8 & 17 & 112 & 68 & 234 \\
\hline \multirow{5}{*}{$\begin{array}{l}2 \text { 年後 } \\
\sim 3 \text { 年後 }\end{array}$} & 9 & 88 & 166 & 100 & 154 \\
\hline & 10 & 47 & 128 & 82 & 236 \\
\hline & 11 & 216 & 142 & 74 & 203 \\
\hline & 12 & 48 & 120 & 74 & 203 \\
\hline & 13 & -27 & 114 & 72 & 141 \\
\hline \multirow{3}{*}{$\begin{array}{l}3 \text { 年後 } \\
\sim 4 \text { 年後 }\end{array}$} & 14 & 58 & 180 & 80 & 203 \\
\hline & 15 & -184 & 114 & 70 & 260 \\
\hline & 16 & -76 & 148 & 78 & 248 \\
\hline \multirow{3}{*}{$\begin{array}{l}4 \text { 年後 } \\
\sim 5 \text { 年後 }\end{array}$} & 17 & 88 & 142 & 66 & 172 \\
\hline & 18 & -89 & 110 & 62 & 201 \\
\hline & 19 & -9 & 182 & 100 & 219 \\
\hline \multirow{3}{*}{$\begin{array}{l}5 \text { 年後 } \\
\sim 6 \text { 年後 }\end{array}$} & 20 & -94 & 144 & 84 & 180 \\
\hline & 21 & -75 & 174 & 82 & 153 \\
\hline & 22 & -263 & 150 & 88 & 215 \\
\hline \multirow{26}{*}{$\begin{array}{c}6 \text { 年後まで } \\
\text { 非発症 }\end{array}$} & 23 & -8 & 136 & 88 & 183 \\
\hline & 24 & -103 & 120 & 78 & 131 \\
\hline & 25 & -154 & 150 & 82 & 175 \\
\hline & 26 & -220 & 98 & 66 & 125 \\
\hline & 27 & -26 & 146 & 78 & 126 \\
\hline & 28 & 17 & 96 & 68 & 185 \\
\hline & 29 & 165 & 124 & 72 & 295 \\
\hline & 30 & -101 & 138 & 78 & 227 \\
\hline & 31 & 66 & 102 & 58 & 169 \\
\hline & 32 & 13 & 99 & 54 & 186 \\
\hline & 33 & 158 & 120 & 80 & 222 \\
\hline & 34 & -85 & 110 & 60 & 143 \\
\hline & 35 & -32 & 122 & 66 & 195 \\
\hline & 36 & -125 & 114 & 64 & 181 \\
\hline & 37 & -85 & 110 & 50 & 174 \\
\hline & 38 & -29 & 118 & 70 & 211 \\
\hline & 39 & -111 & 140 & 82 & 184 \\
\hline & 40 & -76 & 130 & 70 & 116 \\
\hline & 41 & -217 & 114 & 72 & 225 \\
\hline & 42 & -153 & 132 & 70 & 116 \\
\hline & 43 & -107 & 120 & 64 & 147 \\
\hline & 44 & 32 & 146 & 82 & 177 \\
\hline & 45 & 25 & 118 & 82 & 299 \\
\hline & 46 & -68 & 140 & 70 & 198 \\
\hline & 47 & -9 & 120 & 70 & 191 \\
\hline & 48 & -47 & 138 & 78 & 224 \\
\hline
\end{tabular}

項目 1 : 肥満度 $2:$ 収縮期血圧 $3:$ 拡張 期血圧 $4:$ 血清総コレステロール
測る尺度 $\lambda$ と䛊判別数も示した. また, 2 つの調査時点 の判別係数ベクトルの変化を表 4 に示した.

以下に表 3 と表 4 から得られた結果について考察す る.

1）年が経つにつれ，尺度 $\lambda$ が小さくなる。つまり このことは，本例に打いては年々，母集団間の離れ具 合いが小さくなり発症群と非発症群の差異を説明する ことが困難になって行くことを示している.

2） 1 年後から 4 年後の調査に打ける判別係数べク トルの変化は小さいが判別点の值は徐々に減少してい る.これは前年の調査で発症群に近い非発症者が順に 発症したと考学られる。

3） 5 年後と 6 年後に関して, 判別係数ベクトルの 変化が他に比べて大きいことが見られる．このことは 今までと異なる何かが生じたと思われる。

尺度 $\lambda$ のみを考察すると 1 年後の調査を用いれば 良いことになるが，実際問題として不合理である。 た, 判別係数ベクトルの変化という概念を導入すると, 5 年後以後の調査を用いて疾病の要因を調べることは 誤判別数が増していることからあまり良いとはい党な い. 尺度 $\lambda$, 誤判別数, 判別係数ベクトルの変化を総合 すると, 本例では, 3 年後の調査を用いるのが良いとい ら結論を導くことができる。

\section{6. ま と め}

本研究は，時間の経過とともに母集団を移動する観 測值が Fisherの線形判別関数を用いた判別分析の判 別係数ベクトルや判別点に与える影響をモデルを用い て考察したものである。

先ず，判別係数ベクトルに何の影響も扣よぼさない 条件のもとで判別点が変化するのでその変化量を定義 し, 数值例を用いて判別点の変化を様相を具体的に調 ベた，次に，判別係数ベクトルに影響を与える観測值 の状態を調べるため, 判別係数べクトルの変化を表現 する值を定義し，考察した。これらの結果より得られ たことは第 4 章にまとめられている。

最後に，脳卒中の追跡調査を実例として上げ，判別 分析を行なら時点の決定といら実際に直面する問題を 示した。 また，この実例に招いて，判別係数ベクトル の動きを調べ，第 4 章の定理や数值例の結果と照らし 合わして上記の問題を考察した。

$$
\text { 謝辞 }
$$

本研究を進めるにあたり多くの助言を下さった北海 
表 3 各調查時に打ける判別係数と判別点

\begin{tabular}{|c|c|c|c|c|c|c|c|c|c|c|}
\hline \multirow{2}{*}{ 年後 } & \multirow{2}{*}{ 発症者数 } & \multirow{2}{*}{ 非発症者数 } & \multicolumn{4}{|c|}{ 判別係数 } & \multirow{2}{*}{$\begin{array}{l}\text { ノルム } \\
\|\mathrm{a}\|\end{array}$} & \multirow{2}{*}{$\begin{array}{c}\text { 尺度 } \\
\lambda\end{array}$} & \multirow{2}{*}{$\begin{array}{c}\text { 判別点 } \\
h\end{array}$} & \multirow{2}{*}{ 誤判別点 } \\
\hline & & & 1 & 2 & 3 & 4 & & & & \\
\hline 1 & 4 & 44 & .100 & -.540 & .826 & .125 & 4.457 & 1.758 & .657 & 7 \\
\hline 2 & 8 & 40 & .206 & -.627 & .750 & .045 & 3.831 & 1.005 & .350 & 8 \\
\hline 3 & 13 & 35 & .373 & -.594 & .711 & -.056 & 3.839 & 1.071 & .256 & 6 \\
\hline 4 & 16 & 32 & .393 & -.513 & .748 & .149 & 2.014 & 0.481 & .159 & 10 \\
\hline 5 & 19 & 29 & .544 & -.350 & .737 & .195 & 1.395 & 0.360 & .108 & 12 \\
\hline 6 & 22 & 26 & .313 & -.070 & .930 & .179 & 1.052 & 0.295 & .047 & 15 \\
\hline
\end{tabular}

項目 1 : 肥満度 2 : 縮小期血圧 $3:$ 拡張期血圧 $4:$ 血清総コレステロール

表 4 判別係数ベクトルの変化(値 $D$ )

\begin{tabular}{c|r|r|r|r|r|r}
\hline 年度 & \multicolumn{1}{c|}{1} & \multicolumn{1}{c|}{2} & 3 & 4 & \multicolumn{1}{c}{5} & 6 \\
\hline 1 & 1.000 & & & & & \\
2 & .984 & 1.000 & & & & \\
3 & .938 & .980 & 1.000 & & & \\
4 & .953 & .971 & .975 & 1.000 & & \\
5 & .877 & .893 & .924 & .974 & 1.000 & \\
6 & .860 & .814 & .809 & .882 & .915 & 1.000 \\
\hline
\end{tabular}

道大学の河口至商教授ならびに佐藤義治助教授に感謝 の意を表します。また，審査員の方々から有益なご教 示をいただきました，ここに記して感謝の意を表しま †.

\section{付 録 1}

定理 1 の証明

$$
\begin{aligned}
& n_{2}=0 \text { のときは明らか. } \\
& S_{W}^{*(1)}=S+\frac{n_{1} n_{2}}{n\left(n_{1}+n_{2}\right)}\left(\overline{\boldsymbol{x}}_{1}-\overline{\boldsymbol{x}}_{2}\right)\left(\overline{\boldsymbol{x}}_{1}-\overline{\boldsymbol{x}}_{2}\right)^{\prime} \text { の逆行列 }
\end{aligned}
$$

は Bartlett（1951）の結果より

$$
\begin{aligned}
S_{W}^{*(1)^{-1}} & =S^{-1}-k S^{-1}\left(\overline{\boldsymbol{x}}_{1} \overline{\boldsymbol{x}}_{2}\right)\left(\overline{\boldsymbol{x}}_{1}-\overline{\boldsymbol{x}}_{2}\right)^{\prime} S^{-1} \\
& =S^{-1}-k x_{21}^{2} S^{-1} A S^{-1}
\end{aligned}
$$

と表される。ここで

$$
\begin{aligned}
& k=\frac{n_{1} n_{2}}{n\left(n_{1}+n_{2}\right)+n_{1} n_{2} x_{21}^{2} \sigma^{11}} \\
& S^{-1}=\left(\sigma^{i j}\right), \\
& A=\left(\alpha_{i j}\right),\left\{\begin{array}{l}
\alpha_{11}=1, \\
\alpha_{i j}=0(i \neq 1, j \neq 1) .
\end{array}\right.
\end{aligned}
$$

これより

$$
\begin{aligned}
& \frac{h^{(1)}}{\left\|\boldsymbol{a}^{(1)}\right\|}=\frac{-\left\{n_{2} x_{21}+\left(n_{1}+n_{2}\right) x_{3}\right\} \sigma^{11}}{2\left(n_{1}+n_{2}\right) \sqrt{\sum_{i=1}^{p}\left(\theta^{i 1}\right)^{2}}}, \\
& \frac{h^{(2)}}{\left\|\boldsymbol{a}^{(2)}\right\|}=\frac{-\left(n_{2} x_{21}+n_{3} x_{3}\right) \sigma^{11}}{2\left(n_{2}+n_{3}\right) \sqrt{\sum_{i=1}^{p}\left(\sigma^{i 1}\right)^{2}}}
\end{aligned}
$$

であるから，もし $\frac{h^{(1)}}{\left\|\boldsymbol{a}^{(1)}\right\|}=\frac{h^{(2)}}{\left\|\boldsymbol{a}^{(2)}\right\|}$ ならば

$$
\begin{gathered}
\left\{n_{2} x_{21}+\left(n_{1}+n_{2}\right) x_{3}\right\}\left(n_{2}+n_{3}\right) \\
=\left(n_{2} x_{21}+n_{3} x_{3}\right)\left(n_{1}+n_{2}\right)
\end{gathered}
$$

これを変形すると

$$
n_{2}\left\{\left(n_{1}+n_{2}\right)\left(x_{3}-x_{21}\right)+\left(n_{2}+n_{3}\right) x_{21}\right\}=0 .
$$

\{\} の值は常に正だから $n_{2}=0$.

\section{付 録 2}

定理 2 の証明

$$
\begin{aligned}
S= & I \text { のとき } x_{22}>(<) 0 \text { に対して } \\
a_{1}^{(1)}= & \frac{n\left(n_{2} x_{21}-n_{1} x_{3}-n_{2} x_{3}\right)-n_{1} n_{2} x_{22}^{2} x_{3}}{c_{1}} \\
& <(<) 0, \\
a_{2}^{(1)}= & \frac{n_{2} x_{22}\left(n+n_{1} x_{21} x_{3}\right)}{c_{1}}>(<) 0,
\end{aligned}
$$




$$
\begin{aligned}
& a_{1}^{(2)}=\frac{-\left\{n\left(n_{2} x_{21}+n_{3} x_{3}\right)+n_{2} n_{3} x_{22}^{2} x_{3}\right\}}{c_{2}}<(<) 0, \\
& a_{2}^{(2)}=\frac{-n_{2} x_{22}\left\{n+n_{3} x_{3}\left(x_{3}-x_{21}\right)\right\}}{c_{2}}<(>) 0,
\end{aligned}
$$

ここで

$$
\begin{aligned}
& c_{1}=n\left(n_{1}+n_{2}\right)+n_{1} n_{2}\left(x_{21}^{2}+x_{22}^{2}\right)>0, \\
& c_{2}=n\left(n_{2}+n_{3}\right)+n_{2} n_{3}\left\{\left(x_{21}-x_{3}\right)^{2}+x_{22}^{2}\right\}>0 .
\end{aligned}
$$

$a_{q}^{(k)}=0(k=1,2, q=3, \cdots, p)$ は明らか.

\section{参 考 文 献}

Anderson, T.W. (1984). An Introduction to Multivariate Statistical Analysis 2nd Edition, New York: John Wiley \& Sons, Inc.

Bartlett, M.S. (1951). An inverse matrix adjustment arising in discriminant analysis. Annals of Mathematical Statistics 22, 107-111.

Fisher, R.A. (1936). The use of multiple measurements in taxonomic problems. Annals of Eugenics 7, 179-188.

廣田安夫 (1978). 脳血管障害発症の予測, 最新医学, 33, No. 1, 56-57.

Lachenbruch, P.A. (1966). Discriminant analysis when the initial samples are misclassified. Technometrics 8, No. 4, 657-662.

Lachenbruch, P.A. (1974). Discriminant analysis when the initial samples are misclassified II : nonrandom misclassification models. Thechnometrics 16 : No. 3, 419-424.

Lachenbruch, P.A. (1979). Note on initial misclassification effects on the quadratic discriminant functions. Technometrics 21, No. 1 , 129-132.

- 1987 年 4 月受付, 1987 年 8 月再受付一 